\title{
Postpartum uterine diseases in dairy cows: a review with emphasis on subclinical endometritis
}

\author{
Baarmoederaandoeningen na het afkalven bij melkkoeien: een overzicht \\ met nadruk op subklinische endometritis
}

\section{O. B. Pascottini, G. Opsomer}

Department of Reproduction, Obstetrics and Herd Health, Faculty of Veterinary Medicine, Ghent University, Merelbeke 9820, Belgium

geert.opsomer@ugent.be

\begin{abstract}
$\Lambda_{\text {bstract }}$
In this review, updated and precise definitions of the most common postpartum uterine diseases in dairy cows are provided. An aberrant uterine environment at inappropriate stages of the reproductive cycle inflicts damage to gametes and zygotes, impairing the reproductive performance of dairy cows. This involves major economic losses for the milk production unit. Consequently, an accurate diagnosis of postpartum uterine diseases is indispensable for practitioners to set up a prompt and efficient treatment. This review furthermore emphasizes on the new perspectives regarding diagnosis and treatment of subclinical endometritis, a highly prevalent uterine disease that is often overlooked by practitioners while causing major reproductive problems. Based on a more profound clinical understanding of the postpartum uterine disease complex, practitioners will be able to better use the available diagnostic tools and therefore apply a more efficient therapeutic approach.
\end{abstract}

\section{SAMENVATTING}

In dit artikel wordt een geüpdatet overzicht gegeven van de definities van de meest voorkomende baarmoederproblemen na het afkalven bij melkkoeien. Een afwijkend uterien milieu op de meest precaire momenten van de voortplantingscyclus veroorzaakt immers schade aan de gameten en het jonge embryo met finaal nefaste gevolgen voor het voortplantingsvermogen van de koeien. Dit laatste zorgt voor beduidende economische verliezen op veel moderne melkveebedrijven. Vandaar dat het voor de practicus van groot belang is om tot een accurate diagnose te komen teneinde een gerichte en efficiënte behandeling te kunnen instellen. Bovendien wordt in dit artikel bijzondere aandacht besteed aan subklinische endometritis. Deze aandoening is bij practici minder goed bekend terwijl ze bij een relatief groot aantal dieren voorkomt op het moment van inseminatie. Via het aanreiken van diepgaandere kennis omtrent het complex van postpartum baarmoederproblemen, hopen de auteurs met dit artikel de practicus te wijzen op de voorhanden zijnde mogelijkheden om tot een accurate diagnose en dus ook meer efficiënte behandeling te komen.

\section{INTRODUCTION}

Postpartum uterine disease is the leading cause of reproductive inefficiency in dairy cattle (Barlund et al., 2008). Dairy cattle farmed in intensive systems, commonly acquire microbial contamination of the uterus during parturition (Sheldon et al., 2008). Almost all dairy cows (80 to $100 \%$ ) experience bacterial intrauterine contamination immediately after calving (Herath et al., 2006; Sheldon et al., 2009). Due to this fact, as well as due to the substantially required repair of the endometrium following parturition, uterine inflammation is a normal and necessary component of the postpartum uterine involution process (LeBlanc, 2014). However, in a proportion of the postpartum cows, the inflammation runs out of control and leads to uterine disease (Chapwanya et al., 2010).

An elevated postpartum uterine disease incidence contributes to reduced fertility interfering with the main goal of efficient reproductive management: to have cows pregnant at a biologically optimal and economically profitable time after parturition (Sheldon 
Table 1. General overview of the main characteristics of the most common postpartum uterine diseases.

\begin{tabular}{|c|c|c|c|}
\hline $\begin{array}{l}\text { Postpartum uterine } \\
\text { disease }\end{array}$ & Definition & $\begin{array}{l}\text { Days after calving } \\
\text { and reported incidence }\end{array}$ & Treatment \\
\hline $\begin{array}{l}\text { Retention of fetal } \\
\text { membranes }\end{array}$ & $\begin{array}{l}\text { Failure to expulse the } \\
\text { placenta between } 12 \text { to } 24 \mathrm{~h} \\
\text { after parturition }\end{array}$ & $\begin{array}{l}24 \text { hours after parturition } \\
\text { incidence: } 4 \text { to } 12 \%\end{array}$ & $\begin{array}{l}\text { Strong traction is discouraged } \\
\text { Local antibiotics? }\end{array}$ \\
\hline $\begin{array}{l}\text { Metritis } \\
\text { (puerperal and toxic) }\end{array}$ & $\begin{array}{l}\text { Enlarged, atonic uterus } \\
\text { Fetid, watery red-brown } \\
\text { discharge } \\
\text { Signs of systemic illness } \\
\text { (fever }>39.5^{\circ} \mathrm{C} \text {, decreased } \\
\text { milk yield, signs of toxemia) }\end{array}$ & $\begin{array}{l}\text { Within } 21 \text { days after calving } \\
\text { Usually at the end of the } \\
\text { first week after calving } \\
\text { incidence: } 5 \text { to } 15 \%\end{array}$ & $\begin{array}{l}\text { Local Antibiotics? } \\
\text { In case cows become febrile, } \\
\text { systemic antibiotics for } \\
\text { at least } 3 \text { consecutive days } \\
\text { Supportive therapy if required }\end{array}$ \\
\hline $\begin{array}{l}\text { Clinical endometritis } \\
\text { and/or purulent } \\
\text { vaginal discharge }\end{array}$ & $\begin{array}{l}\text { Local inflammation of the } \\
\text { endometrium } \\
\text { (clinical endometritis) } \\
\text { Presence of purulent or } \\
\text { mucopurulent material in } \\
\text { the vagina (PVD) } \\
\text { Absence of systemic } \\
\text { symptoms (fever) }\end{array}$ & $\begin{array}{l}\geq 21 \text { days after parturition } \\
\text { incidence: } 20 \text { to } 30 \%\end{array}$ & $\begin{array}{l}\text { Intrauterine antibiotics } \\
\text { (cephapirin) } \geq 26 \text { after } \\
\text { parturition } \\
\text { Benefit of PGF } 2 \alpha \\
\text { is not clear }\end{array}$ \\
\hline Pyometra & $\begin{array}{l}\text { Presence of purulent material } \\
\text { in the uterine lumen } \\
\text { Corpus luteum present } \\
\text { Cervix often closed }\end{array}$ & $\begin{array}{l}\text { Depending on the days } \\
\text { post calving after } \\
\text { first ovulation } \\
\text { incidence: } 1 \text { to } 2 \%\end{array}$ & $\begin{array}{l}\text { Two doses of PGF } 2 \alpha \\
\text { with an interval of } \\
11 \text { to } 14 \text { days between } \\
\text { applications }\end{array}$ \\
\hline Cytological endometritis & $\begin{array}{l}\text { Abnormal presence of } \\
\text { PMNs in endometrial } \\
\text { cytology samples } \\
\text { Absence of clinical sign } \\
\text { of purulent vaginal discharge }\end{array}$ & $\begin{array}{l}\text { Diagnosed between } \\
21 \text { to } 64 \text { days after calving } \\
\text { or during AI } \\
\text { incidence: } 9 \text { to } 76 \% \\
\text { most commonly between } \\
25 \text { to } 35 \%\end{array}$ & $\begin{array}{l}\text { Intrauterine antibiotics } \\
\text { (cephapirin) or PGF2 } \alpha \\
\text { (both under discussion) } \\
\text { Therapeutic flushing of } \\
\text { the uterus? }\end{array}$ \\
\hline
\end{tabular}

et al., 2006; Gilbert, 2016). An inflammatory milieu at inappropriate stages of the estrus cycle interferes with fertility by creating suboptimal conditions for sperm transportation and storage, oocyte maturation and ovulation, zygote development, implantation, and embryonic and fetal growth (Gilbert, 2011). In this context, subclinical endometritis (SCE) is a highly prevalent disease that runs without clinical symptoms significantly impairing the fertility of dairy cows (Sheldon et al., 2006; Barlund et al., 2008). However, standardization of SCE diagnosis is not fully established yet (Pascottini et al., 2015). Therefore, an updated and clear definition of the postpartum uterine diseases may help practitioners in order to properly examine and accurately diagnose postpartum cows to set up an efficient treatment prior to the start of the breeding period.

Thus, the aim of this paper was to review the postpartum uterine disease complex, such as retention of fetal membranes (RFM), clinical metritis (CM), clinical endometritis (CE) and/or purulent vaginal discharge (PVD), and pyometra; with particular emphasis on SCE (Table 1).

\section{RETENTION OF FETAL MEMBRANES}

Retention of fetal membranes or retained placenta is the failure to expulse the placenta between 12 to 24 hours after parturition (Paisley et al., 1986; Fourichon et al., 2000; Drillich et al., 2003). If RFM occurs, the membranes are retained in the uterine lumen for an average of seven days (Eiler, 1997), enhancing bacterial contamination and delaying uterine involution (Laven and Peters, 1996). The incidence of RFM ranges from 4 to $12 \%$ (Drillich et al., 2003), with a median incidence rate of $8.6 \%$ (Kelton et al., 1998). Predisposing factors are twins, dystocia, stillborn calf, abnormal length of gestation, induced parturition, abortion, nutritional imbalance, fetotomy, cesarean section, increasing age and seasonal effects (Laven and Peters, 1996; Beagley et al., 2010). Retained placenta has no direct impact on the milk production, reproduction or culling if the condition does not evolve to CM, CE, or SCE (Dubuc, 2011). The increased risk of the previously mentioned diseases constitutes the main reason of the economic importance of RFM. A variety of methods has been used to treat RFM; nevertheless, the topic is still controversial. Manual removal, 
local antibiotics and ecbolic drugs are commonly used treatments, although current evidence does not support their use (Laven and Peters, 1996; Stevens and Dinsmore, 1997; Gilbert, 2016). Intrauterine infusion of oxytetracycline is a common treatment among practitioners. It may reduce the incidence of subsequent fever (Stevens et al., 1995). However, it has no effect on the subsequent reproductive performance (Goshen and Shpigel, 2006), and is associated with detectable milk residues, which can persist up to 144 hours (Dinsmore et al., 1996). Moreover, the local antibiotic therapy (especially with tetracyclines) may prolong the placental retention due to its ability to inhibit matrix metalloproteinases (Gilbert, 2016). In case cows become febrile, systemic antibiotics (ceftiofur) appear to be beneficial in reducing disease and aiding in the return to normal reproductive function (Beagley et al., 2010). However, in many, especially European countries, the systemic use of broad spectrum antibiotics is currently severely under pressure because of the potential association with the increase of antibiotic resistance.

\section{CLINICAL METRITIS}

Clinical metritis is characterized by an enlarged uterus and a watery, red-brown fluid to viscous, offwhite purulent uterine discharge, which often has fetid odor, occurring within 21 days postpartum (Sheldon et al., 2006). The diagnosis of CM is made on the basis of clinical signs of fetid uterine discharge and/ or systemic illness. The severity of the disease has been categorized according to the health signs of the animal in grades 1, 2 and 3 (Sheldon et al., 2009). Clinical metritis grade 1 is characterized by an abnormally enlarged uterus and uterine discharge without systemic signs of illness (Sheldon et al., 2006). Clinical metritis grade 2 (or puerperal metritis) refers to animals that suffer from additional signs of systemic illness, such decreased milk production, dullness, and fever $>39.5^{\circ} \mathrm{C}$ (Sheldon et al., 2006). Clinical metritis grade 3 (or toxic metritis) includes animals with clinical signs of toxemia, such as inappetence, cold extremities, depression, and/or collapse (Sheldon et al., 2009). The incidence of CM is between 15 to $20 \%$, but it can be much higher in some herds (Gilbert, 2016). Risk factors for any degree of CM are often associated with RFM, dystocia, stillbirth or twins. Clinical metritis usually occurs at the end of the first week after calving, being less common after the second week postpartum (Markusfeld, 1984; Drillich et al., 2001). The impact of metritis on the milk production and reproduction is controversial (Dubuc, 2011). When reported as detrimental, the impact on milk production is between 2 and $13 \mathrm{~kg}$ of milk per day during a period of 2 to 20 weeks (Overton and Fetrow, 2008; Wittrock et al., 2009; Giuliodori et al., 2013). Giuliodori et al. (2013) proposed that puerperal CM is associated with an impaired early pregnancy rate and

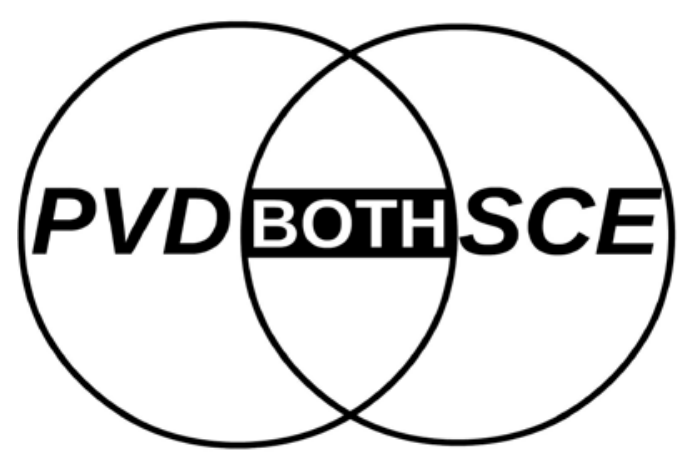

Figure 1. Cows may develop different uterine disease statuses: purulent vaginal discharge (PVD; cervicitis/ vaginitis) only, subclinical endometritis (subclinical endometritis, SCE) only, or both PVD and SCE (clinical endometritis) (Adapted from Dubuc et al., 2010).

an extended calving to conception interval, while in other studies no link was found between CM and a decline in reproductive capacity (Dubuc, 2011). A common treatment for CM (puerperal/toxic) is the intrauterine infusion of antibiotics. However, the efficacy of a local antibiotic treatment is a controversial issue (Drillich et al., 2001). Nowadays, the use of systemic antibiotics (ceftiofur for three consecutive days) in cows with an abnormal vaginal discharge at days 4 to 6 after calving and a rectal temperature $\geq 39.5^{\circ} \mathrm{C}$ has gained popularity and is the most used treatment for puerperal/toxic metritis (CM grade 2 and 3), although this treatment has become controversial in terms of prudent use of antibiotics (Drillich et al., 2001; Zhou et al., 2001). In a recent, randomized clinical trial, the efficacy of the initial use of ketoprofen versus ceftiofur was studied in cows with CM to reduce the usage of antibiotics (Pohl et al., 2016). However, no beneficial effects were found when cows were initially treated with ketoprofen only; finally more doses of medical applications had to be expected (Pohl et al., 2016).

\section{CLINICAL ENDOMETRITIS AND/OR PURU- LENT VAGINAL DISCHARGE}

Clinical endometritis is basically referring to a local inflammation of the endometrium, characterized by the presence of purulent or mucopurulent ( $>$ $50 \%$ pus) material in the vagina $\geq 21$ days postpartum originating from the uterus, not accompanied by systemic illness (Sheldon et al., 2006; Dubuc et al., 2010 ). It affects around $20 \%$ of dairy cows between 21 to 40 days postpartum (LeBlanc et al., 2002a). Usually, CE is diagnosed by means of a vaginoscope, a gloved hand or the metri-check (McDougall et al., 2007; Pleticha et al., 2009). However, it has become clear that the presence of abnormal vaginal exudate may not precisely be related to endometrial inflam- 
mation. Endometritis requires endometrial cytology or biopsy (or ultrasound examination) for a convincing diagnosis (Gilbert, 2016). The presence of vaginal exudate nowadays is referred to as 'purulent vaginal discharge' (PVD). It is generally assumed that PVD is the result of endometritis, cervicitis/vaginitis or the combination of both (Dubuc et al., 2010; Deguillaume et al., 2012) (Figure 1). The prevalence of endometritis alone is around $13 \%$, cervicitis only $11 \%$, while $32 \%$ of the cows suffer from both conditions (Deguillaume et al., 2012). The detrimental effects of endometritis and cervicitis/vaginitis on reproductive performance are additive (Dubuc et al., 2010). In general, cows affected with PVD need on average thirthy days more to become pregnant than unaffected cows (LeBlanc, 2008; Dubuc et al., 2010; Dubuc, 2011). Currently, several controversial reports on the efficiency of treatment protocols for CE/PVD are available in the literature. However, two main approaches are commonly used: parenteral injections of prostaglandins (PGF2 $\alpha$ ) and intrauterine antibiotics (Lefebvre and Stock, 2012). Prostaglandins have been reported to be slightly beneficial (Kasimanickam et al., 2006) or inefficient (Galvão et al., 2009a). Routine use of PGF2 $\alpha$ after 30 days postpartum may be relevant, but there is lack of evidence to sustain its efficiency (Dubuc, 2011). The use of an intrauterine cephapirin application after 26 days postpartum has been proven to be useful for treating PVD (LeBlanc et al., 2002b; McDougall, 2003; Runciman et al., 2008; Dubuc, 2011; Lefebvre and Stock, 2012; Tison et al., 2016).

\section{PYOMETRA}

Pyometra is defined as the accumulation of purulent or mucopurulent material in the uterine lumen provoking a distension of the uterus, accompanied by the presence of an active corpus luteum (Sheldon et al., 2006). In pyometra, the cervix is often functionally closed, although its lumen is not always completely occluded, and some purulent material may discharge through the cervix, vagina or vulva (Sheldon et al., 2006). Based on a large field study (Busch and Kuhnke, 2000 ), pyometra showed to affect approximately 1.2 $\%$ of the investigated cows, and the affection was related to problems during the postpartum period in most of the cases (Opsomer et al., 2000). Generally, ovulation is delayed in cows with a pathologic uterine load (Sheldon et al., 2002), but in case the cows do ovulate during an ongoing uterine infection, pyometra may develop (Gilbert, 2016). The diagnosis of pyometra can be done by rectal palpation and/or ultrasound, echography being the preferred and most accurate method to diagnose the disease. Treatment is based on the injection of two doses of PGF2 $\alpha$ an with an interval of 11 to 14 days between the applications, with a fair rate of healing (Gustafsson et al., 1976; de Kruif et al., 1977; Olson et al., 1986). The prognosis after PGF treatment is generally favorable, with a first service conception rate of approximately $30 \%$ and an expected pregnancy rate of $80 \%$ after three or four inseminations (de Kruif et al., 1977; Fazeli et al., 1980).

\section{SUBCLINICAL ENDOMETRITIS}

Subclinical endometritis plays a critical role in the modern dairy industry. It is highly prevalent, asymptomatic and has a profound detrimental effect on the reproductive performance (Sheldon et al., 2006; Barlund et al., 2008). Subclinical endometritis has been indeed one of the most important reproductive impairments in dairy cows studied in the last decade (Pascottini et al., 2015). It is defined as a superficial inflammation of the endometrium, evidenced by relative increase in the number of PMNs in the uterine lumen, without visible clinical signs, but significantly impairing fertility (Bondurant, 1999; Kasimanickam et al., 2004; Gilbert et al., 2005; Sheldon et al., 2006). As SCE cannot be detected by simple visual inspection, complementary examinations are necessary for its diagnosis, being histopathology, ultrasonography, leukocyte esterase strips (LES) and endometrial cytology.

\section{Endometrial biopsy and histopathology}

In the bovine and equine literature, histopathology is considered the gold standard to diagnose endometrial alterations because it allows to directly visualize both acute and chronic changes of the endometrium (Bonnett et al., 1991; Chapwanya et al., 2010; Pascottini et al., 2016b) (Figure 2). In mares, for many years endometrial biopsy sampling has been regarded as an integral part of breeding soundness evaluation (Van Camp, 1988; Snider et al., 2011). However, in cattle, endometrial biopsy is rarely used since it is considered to be time-consuming, expensive and potentially detrimental for further fertility (Miller et al., 1980; Etherington et al., 1988; Bonnett, 1989; Sheldon and Dobson, 2004; Sheldon et al., 2006).

In an attempt to facilitate the SCE diagnosis and substitute the use of endometrial biopsy, it has been compared with endometrial cytology in mares (Overbeck et al., 2011; Nielsen et al., 2012) and in cows (Meira Jr et al., 2012; Madoz et al., 2014; Bogado Pascottini et al., 2016; Pascottini et al., 2016b). In general, these studies demonstrate that the agreement between cytology and histopathology (as the gold standard) is moderate, with a low sensitivity but very high specificity (Pascottini et al., 2016b). Cytology methods underestimate the health status of the endometrium of dairy cows. Generally, cytologic diagnosis is based on the mere visualization of the PMNs' proportion. On the other hand, histological examination of the endometrium may also reveal chronic changes, such as periglandular fibrosis, angiosclerosis, endometrial gland atrophy or lymphoid aggregates (Sheldon et al., 2006; Snider et al., 2011). Indeed, after re- 


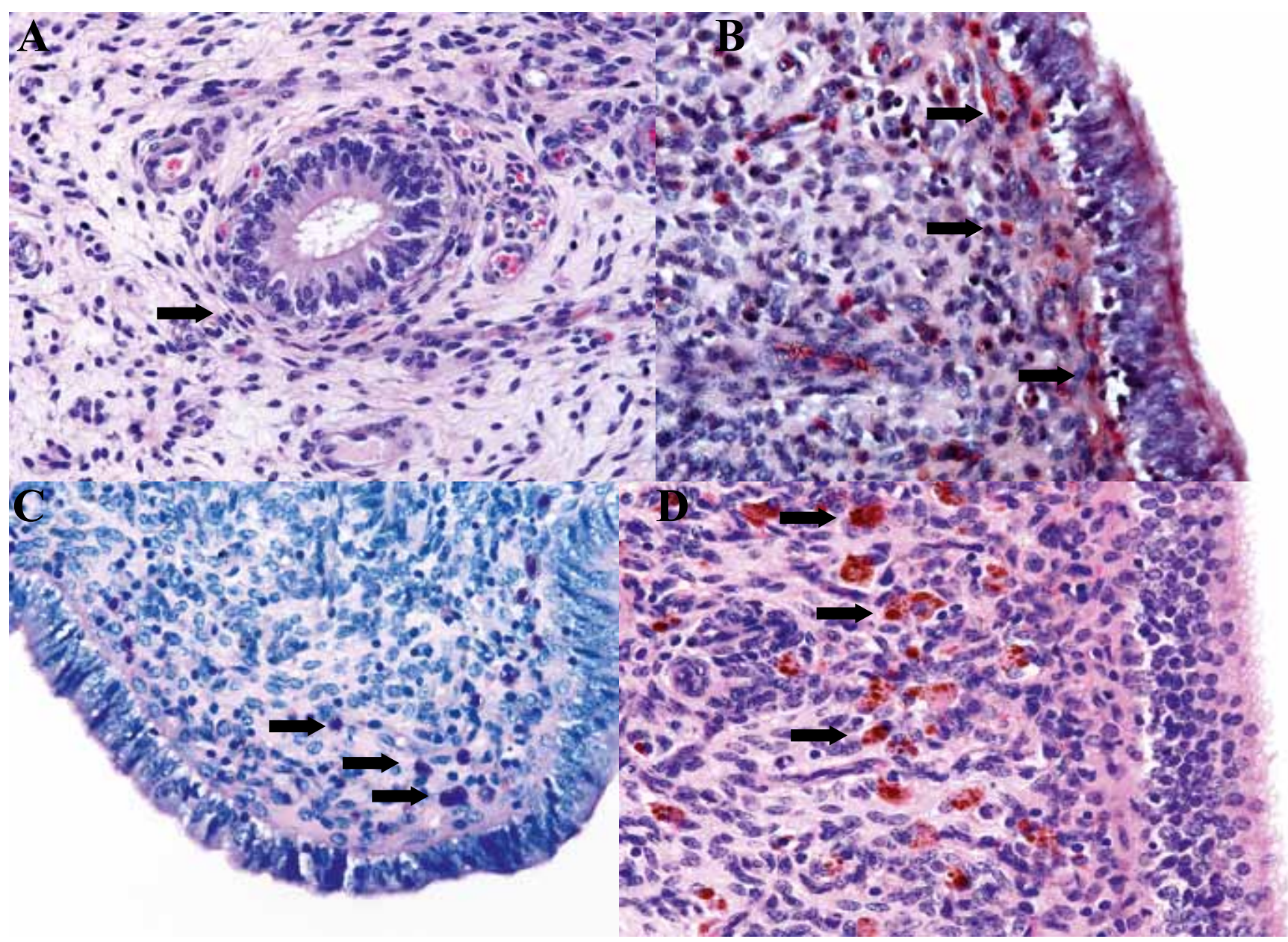

Figure 2. A. Mild periglandular fibrosis (arrow) in an endometrial histopathology sample stained with hematoxylin and eosin B. Polymorphonuclear cells stained in bright red (arrows) in an endometrial histopathology sample stained with Naphtol-AS-D-chloroacetate-esterase C. Mast cells (arrows) in an endometrial histopathology sample stained with Giemsa D. Hemosiderin (in macrophages; arrows) in an endometrial samples stained with hematoxylin and eosin.

covering from active endometritis (PMN infiltration), chronic alterations may persist (Sheldon et al., 2006), being left unnoticed when only applying cytological analysis (Bogado Pascottini et al., 2016). Therefore, a definitive conclusion about the uterine health can only be reached by an endometrial biopsy. However, to the best of the authors' knowledge, there are currently no papers available confirming the use of endometrial histopathology to accurately predict the reproductive capacity of the cow.

\section{Subclinical endometritis and ultrasound}

Nowadays, ultrasonography is considered to be an indispensable part of a routine clinical examination of the reproductive tract of dairy cows (Ginther, 2014). In this context, its potential to diagnose SCE has been demonstrated by multiple authors (Kasimanickam et al., 2004; Barlund et al., 2008; Meira Jr et al., 2012). The presence of fluid in the uterus between 20 to 47 days postpartum has shown to be associated with a significant reduction in the relative pregnancy rate in comparison to cows that appeared "clean" at examination (Kasimanickam et al., 2004; López-Helguera et al., 2012; Gobikrushanth et al., 2016; Šavc et al., 2016). However, the agreement between ultrasound and endometrial cytology is low, meaning that ultrasound and cytology measure two different representations of SCE. On the one hand, the clearance mechanism of the uterus (luminal fluid) and on the other, the cellular response of the inflamed uterus (PMNs in cytology slides) (Kasimanickam et al., 2004; Barlund et al., 2008). Another parameter used to diagnose $\mathrm{SCE}$, is the endometrial thickness measured by ultrasound. However, this technique is underused since it can easily be influenced by the location of the probe on the uterine horn. Consequently, although ultrasonography is an easy and fast technique to apply in practice, it is considered to be not accurate when it is not accompanied with endometrial cytology (Barlund et al., 2008).

\section{Leukocyte esterase colorimetric strips (LES)}

LES has been used for rapid diagnosis of inflammation in fluids, such as urine, pleural, peritoneal and cerebrospinal fluid (Couto et al., 2013). Leukocyte esterase is a an enzyme produced by neutrophils, and 
is therefore known to be indicative for inflammation. LES has been used as an indirect method to detect inflammation due to its reaction with the diazoniun salt released indoxil, which is oxidized, yielding a violet azo dye (Kutter et al., 1987). The intensity of the dye is related with the leukocyte counts. In order to create a "cow side" diagnostic method for SCE, LES were tested to assess their potential to diagnose SCE (Cheong et al., 2012; Couto et al., 2013; DenisRobichaud and Dubuc, 2015a). Although results obtained by LES are positively correlated with endometrial cytology results (Cheong et al., 2012; Couto et al., 2013), they initially were not correlated with the odds of pregnancy (Couto et al., 2013). However, in a recent large study by Denis-Robichaud and Dubuc (2015a), a strong correlation was found between the LES results and the odds to become pregnant. Consequently, the authors considered the use of LES as a valid alternative for on-farm SCE diagnosis. However, to fully recommend the use of leukocyte esterase reagents as a cow-side diagnostic tool for SCE, this method needs further refinement (Cheong et al., 2012).

\section{Endometrial cytology}

Endometrial cytology is the most used technique to diagnose SCE in cattle in both field and research setups (Dubuc et al., 2010, de Boer et al., 2014). The assessment of the proportion of PMNs in cytology slides is the hallmark for SCE diagnosis, to the point that some authors refer bovine SCE to as "cytological endometritis" (CYTO) (de Boer et al., 2014) (Figure 3). Similarly to PVD, CYTO diagnostic criteria are established based on subsequent reproductive performances (Dubuc, 2011). In general, in comparison to their negative counterparts, cows affected by CYTO experience a detrimental effect regarding their reproductive capacity (Gilbert et al., 2005; Galvão et al., 2009a; Dubuc et al., 2010). Although there is no impact of CYTO on milk production (Dubuc, 2011), its importance is mainly based on the increased time to pregnancy (Gilbert et al., 2005) and the concomitant economic loss (Dubuc, 2011). Assuming that each "extra" open day costs to the farmer approximately 2 euro (Plaizier et al., 1997; De Vries, 2006), and that a CYTO positive cow has on average an increased time to pregnancy of 25 days (Gilbert et al., 2005; Dubuc et al., 2010), CYTO associated costs reach up to 50 euro per positive cow, plus the cost (material and service) of extra unsuccessful inseminations and eventual treatments. Moreover, CYTO has been shown to be a highly prevalent disease ranging on average from 20 to $30 \%$ of examined postpartum cows (Dubuc, 2011).

Endometrial cytology techniques in dairy cows: cytobrush and low volume lavage

Cytology is the science that evaluates the structure, chemistry and functionality of the cells (Grunze and Spriggs, 1983). Polymorphonuclear granulocytes represent the first and principal immunologic defense mechanism in the uterus (Sheldon and Dobson, 2004; Herath et al., 2006; Singh et al., 2008; Sheldon et al., 2009). Thus, an elevated number of PMNs in the uterine lumen indicates an inflammatory reaction of the endometrium (endometritis). Different techniques have been described to obtain endometrial samples for cytological examination in both mares and cows (Ball et al., 1988; Kasimanickam et al., 2004; Card, 2005; Gilbert et al., 2005; Barlund et al., 2008; Overbeck et al., 2011; Cocchia et al., 2012; Pascottini et al., 2015). In cows, cytobrush (CB) and low volume lavage (LVL) are the most used techniques to harvest endometrial surface scrapings. The CB consists of a small brush that is commonly used to sample cells from the vagina, cervix or endocervix for Papanicolaou testing in women (Venes, 2013). As such, CB use was first reported in women to collect cervical samples to diagnose malign tumors (Glenthøj et al., 1985). In 2004, for the first time, the CB was adapted to harvest endometrial samples in cows (Kasimanickam et

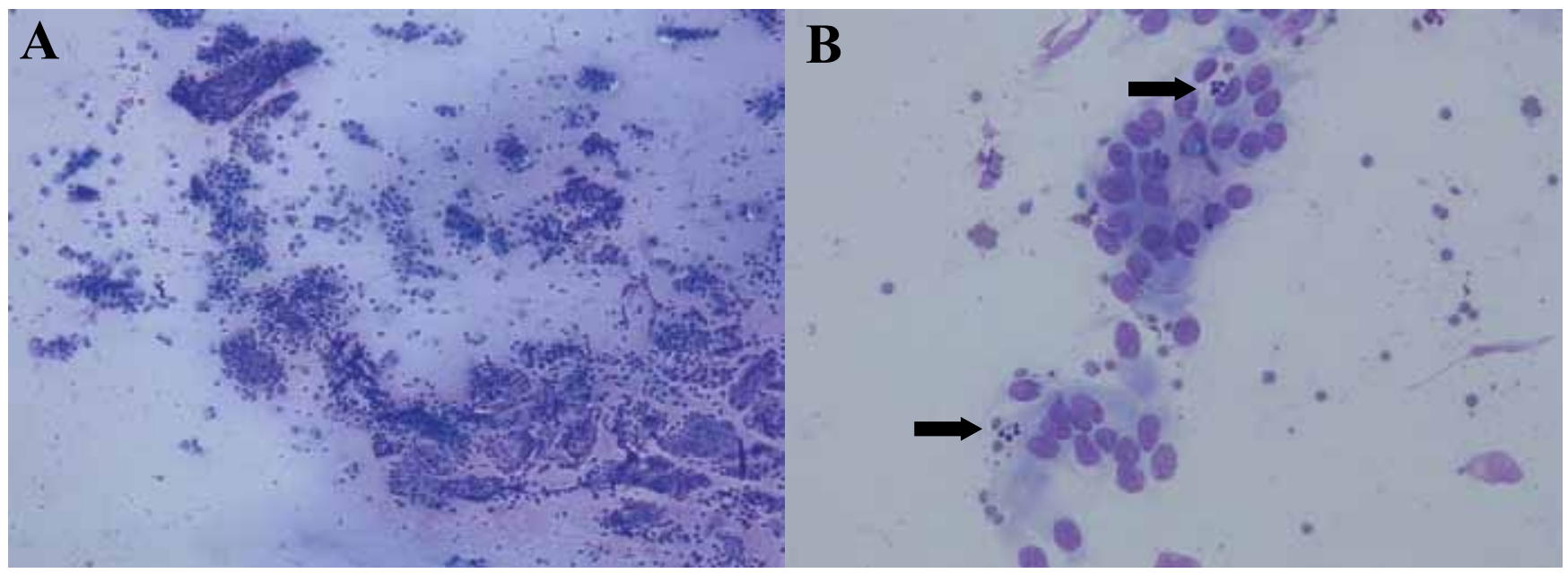

Figure 3. Endometrial cytology smears stained with Diff-Quick ${ }^{\circledR}$, observed by light microscope. A. 100x, B. 400x (arrows point at polymorphonuclear cells). 
al., 2006). On the other hand, the cytologic sampling technique "low volume uterine flushing" was firstly described by Ball et al. (1988) in mares, and subsequently modified by Gilbert et al. $(1992 ; 2005)$ for its use in cows. However, CB and LVL lavage techniques are essentially based on different approaches (Pascottini et al., 2016b). Each technique has particular advantages and disadvantages. For example, when the uterine cavity is flushed with the liquid infused during LVL sampling, it harvests cells and debris present in the uterine lumen, and probably the superficial layer of the endometrial epithelium (Kasimanickam et al., 2005b) sampling the majority of the uterine surface. The CB technique on the other hand only samples a very limited portion of the endometrium, and loose PMNs are therefore only locally collected (Pascottini et al., 2016b).

Cytotape: a novel cytological sampling technique to diagnose cytological endometritis in dairy cows

Although the importance of CYTO on the fertility and profitability of dairy farms is largely known, standardization of endometrial cytology diagnosis in dairy cows has not been fully established yet (Pascottini et al., 2015) (Table 2). In different publications, the time relative to calving the samples were taken varied from 21 to 64 DIM (Kasimanickam et al., 2004; Gilbert et al., 2005; Hammon et al., 2006; Barlund et al., 2008). Concomitantly, PMN threshold levels to diagnose CYTO ranged from 3 to $18 \%$ (Salasel et al., 2010; de Boer et al., 2014) resulting in a wide variation (9 to $76 \%$ ) in reported CYTO prevalence (Barański et al., 2012). Consequently, comparing results between studies is almost unfeasible. However, a novel technique, cytotape (CT), was developed to take endometrial samples at the moment of AI (Pascottini et al., 2015). Cytotape consists of a 1.5 piece of paper tape rolled on the tip of a standardly loaded insemination gun, covered with a double guard sheath. This simple technique has achieved high cytology standards when compared with the cytobrush, its main advantage being the possibility to sample cows during AI by using ordinary material (Pascottini et al., 2015) (Figure 4). Sampling during AI obviously has three significant benefits: (1) standardization of the moment of sampling and assessment of the uterine health status at the most critical point, being the moment of insemination; (2) allowing the use of a universal PMN cutoff point, as the moment of sampling is standardized; and (3) no extra manipulation of the animal is required, as CYTO sampling and AI are performed simultaneously. However, it may be arguable that sampling during estrus might lead to false-positive results since a higher PMN infiltration during estrogenic dominance (histopathology) has been reported (Ohtani et al., 1993; Subandrio et al., 2000). Still, Madoz et al. (2013) suggested that the physiological infiltration of PMNs was not related to the stage of the estrous cycle, at least in studies based on cytologic samples. This is in concordance with the results obtained by the authors (Pascottini et al., 2016a, Pascottini et al., 2016c), where the absence of PMNs in a high number of cytology samples harvested during AI was demonstrated.

In two large field studies performed by the research group of the Department of Reproduction, Obstetrics and Herd Health, Faculty of Veterinary Medicine (Ghent University) using the cytotape device, a universal PMN cut off point of $1 \%$ in cytology samples achieved during AI was established in both dairy cows and nulliparous dairy heifers (Pascottini et al., 2016a; Pascottini et al., 2016c). More than one quarter of the modern dairy cows that are inseminated, suffer from CYTO, with a substantial detrimental effect on fertility (conception rate in CYTO negative samples $47 \%$ versus $32.7 \%$ in CYTO positive samples). As expected, the prevalence of CYTO was low $(7.9 \%)$ in nulliparous dairy heifers. This may probably be attributed to the fact that these animals did not experience a prior parturition and concomitant damage and bacterial contamination. However, in nulliparous dairy heifers, the conception rate in CYTO negative samples was $62.8 \%$ while it was only $38.5 \%$ in CYTO positive samples. Risk factors associated with CYTO prevalence were different in cows versus nulliparous heifers. In cows, risk factors associated with CYTO occurrence were parity $\geq 2$, DIM at $\mathrm{AI} \geq 124$, and warm months of the year. On the other hand, the only risk factor associated with CYTO occurrence in nulliparous heifers was the performance of a previous unsuccessful insemination. These studies clearly demonstrate the deleterious effect of CYTO diagnosed at $\mathrm{AI}$ and the importance of its diagnosis on a regular basis in order to set up specific management decisions and eventually specific treatments.

Innovative perspectives in CYTO diagnosis and treatment

The examination by $\mathrm{CT}$ during first insemination allows the exploration of uterine health without any extra labor cost. If the breeding is not successful and the cow is diagnosed CYTO positive, it will be possible to set up a more targeted treatment to increase the odds of pregnancy at a subsequent AI. The use of this new tool could furthermore be interesting when inseminating and simultaneously sampling repeat breeder cows, aiming to more accurately diagnose the underlying reason of the repeat breeding. However, it is important to mention that currently no consensus exists concerning an effective CYTO treatment. The use of PGF $2 \alpha$ during diestrus results in luteolysis and, subsequently, estrus, which has been suggested to enhance local immunity by removal of the immunosuppressive effect of progesterone (Lewis, 2003, Lewis, 2004). Furthermore, PGF2 $\alpha$ is claimed to possess an ecbolic effect, by which it effectuates the elimination of bacteria and debris (Lima et al., 2013). However, 
Table 2. Summary of subclinical endometritis studies around the world, considering different time points postpartum, thresholds for percentage of polymorphonuclear cells and respective prevalence.

\begin{tabular}{llccc}
\hline Reference & Country & Days in milk & PMN (\%) & Prevalence (\%) \\
\hline Kasimanickam et al. (2004) & USA & $20-33$ & $>18$ & 45 \\
Dubuc et al. (2010) & Canada & $34-47$ & $>10$ & 41 \\
& & $35 \pm 3$ & $\geq 6$ & 13.5 \\
Plöntzke et al. (2010) & Argentina & $56 \pm 3$ & $\geq 4$ & 9.6 \\
& & $18-38$ & $>5$ & 38 \\
McDougall et al. (2011) & New Zealand & $32-52$ & $>5$ & 19 \\
\multirow{2}{*}{ Bogado Pascottini et al. (2016) } & \multirow{2}{*}{ Belgium } & $29 \pm 2.4$ & $\geq 9$ & 29 \\
& & $43 \pm 2.3$ & $\geq 7$ & 27.8 \\
\hline
\end{tabular}

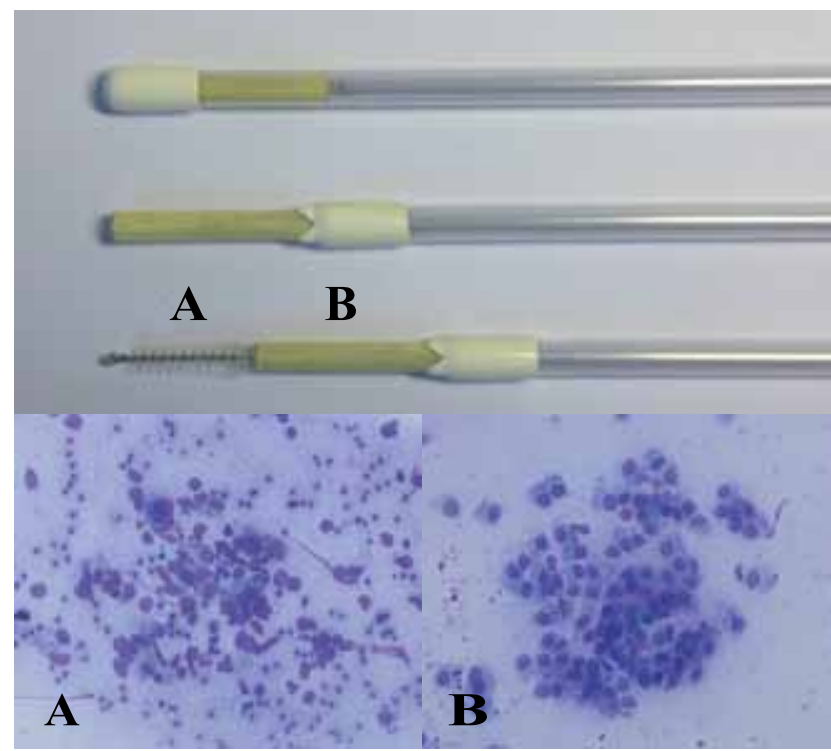

Figure 4. A. Cytobrush sample with fragmented cells and moderate red blood cell contamination. B. Cytotape sample exhibiting good quality (intact) endometrial cells.

only one study showed a significant benefit of PGF $2 \alpha$ treatment on CYTO prevalence (Kasimanickam et al., 2005a), whereas other studies did not (Galvão et al., 2009a, Lima et al., 2013). Some authors unsuccessfully tried to correlate the presence of CYTO with bacterial infection (McDougall et al., 2011; Barański et al., 2012; Madoz et al., 2014). However, others have demonstrated the benefits of an intrauterine antibiotic treatment (Kasimanickam et al., 2005a, DenisRobichaud and Dubuc, 2015b), but not Galvão et al. (2009b). Recently, The authors of this review demonstrated the possibility to reduce the amount of PMNs present in the uterine lumen by applying a uterine lavage with 500 to $600 \mathrm{~mL}$ of a sterile saline solution (Dini et al., 2015). However, further field studies are necessary to confirm this as a potential treatment for repeat breeder cows suffering from CYTO. Contradictory results have been put forward regarding the application of non-steroidal anti-inflammatory drugs following AI (Hirsch and Philipp, 2009; Erdem and Guzeloglu, 2010; Heuwieser et al., 2011). However, such a treatment specifically targeted for cows suffering from CYTO diagnosed at AI could represent a valid strategy to improve the pregnancy outcome of that AI.

\section{CONCLUSION}

Approximately $50 \%$ of dairy cattle develop uterine disease after parturition. In this review, the latest clinical definitions and the most efficient therapeutic approaches of the postpartum uterine disease complex were exposed. However, the main aim of farmers and practitioners should be focused on the prevention of the risk factors associated with uterine diseases. More research is needed in order to reduce the uterine diseases prevalence by applying strategic management decisions on nutrition, genetics and preventive medicine.

\section{REFERENCES}

A comprehensive reference list is available upon request. 